\title{
A new note for Nat
}

Rock on.

\section{Gareth Owens}

Nat used to be in a band. Until yesterday that was. That's him, sat in the armchair, the unhappy looking one talking to Midge. And there's Duffy and Slingshot. And that's me in the other corner.

You can't always see me on the screen, Tim was holding the camera. I'm only the manager, and it was the band we wanted to catch. This was a promo, backstage thing for the website.

This was taken about three years ago, back in the day when Invisible Ear was the biggest band on three continents. You must have been living under a rock to have missed them, even if you couldn't actually hear anything they did. They were the crest of a wave, first of a new breed, pioneers on the new frontier. And I can honestly say that I've never heard a single note that they've ever played. Not that I'm that bothered, they have made me a very happy man over the past few years. M. Osborne, manager to the stars, known to one and all as Mozzy. I have bands queuing up for me now, and I owe it all to Nat and the gang.

But there would have been no Invisible Ear at all, no career for Nat, or for me, if it hadn't been for an irritated shopkeeper.

The problem this guy had was he wanted to discourage gangs of youngsters from hanging around his shop, putting off his paying customers. His solution was to put a buzzing box by the door that made an irritating high-pitched sound that only the youngsters could hear. 'Dults lose their hearing from the top down, so the older customers could come in and spend money without any problem, but anyone under the age of about 18 would have this constant buzz, like toothache. Really put them off.

Well, kids ain't stupid. They took to this idea that there's stuff they can hear that the 'dults can't and made it their own. Suddenly there were ring-tones for cell phones just for them, and that was when Nat and Slingshot had the idea to get together and begin Invisible Ear. They started writing tunes in this register. A music that was theirs and theirs alone. No grown-ups allowed, 'dults keep-out.

I was always on the lookout for the next

big thing, and I saw Invisible Ear play at a school hall. I wasn't expecting much. School bands are usually awful, shouting boys doing covers of angry music, but this was something else. Nat raised his hands in the air, counted the band in with a one-two-three and they started to play. The audience went wild. I could see heads bobbing up and down, and they danced around to this invisible beat, and yet I could hear nothing, nada, zip and zilch.

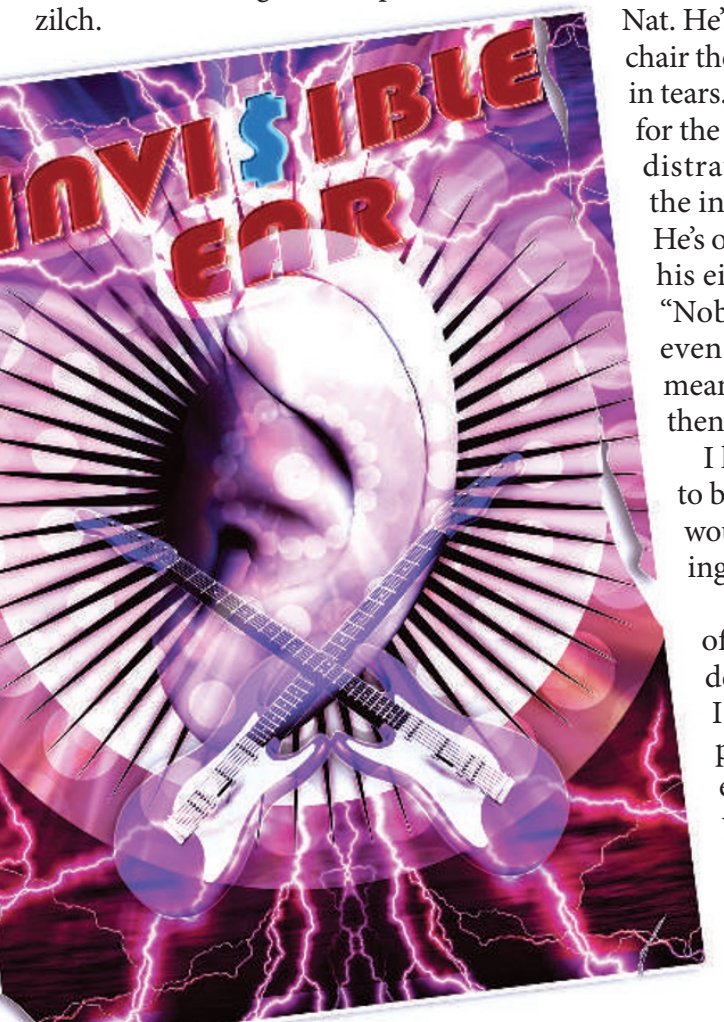

would nod, and look like they were getting into it, and about half the time Nat hadn't switched the player on.

Invisible Ear took the world by storm. Not only music but vids, games and online worlds, Japanese children would queue for hours just to get the latest Ear game to play at home. They became a worldwide cultural phenomenon.

Then yesterday, at the height of the band's fame and popularity, they sacked Nat. He's too old you see. He sat in that chair there and the poor kid was almost $₫$ in tears. He's been wearing hearing aids for the past six months. He was totally distraught, been tryin' to hold off the inevitable, but what can you do? He's over the hill four months before his eighteenth birthday. I told him: "Nobody can keep time at bay, not even you Nat. You founded a club meant to keep grown-ups out - and then you grew up. Sorry."

I let him wallow for a while, but to be honest what kind of manager would I be if I hadn't seen this coming?

"Look, Nat. Take those things off your ears, you are not going deaf." I didn't give him the choice. I walked over to where he sat and pulled the hearing aids off his ears, he yelped a bit. "Like I said, you founded a club for the youth market, but you're not the only one getting older. The record company is beginning to get complaints that the recordings they made of Invisible Ear's

I stood amazed and puzzled. For the next three minutes the band played, and Nat sang (he recorded vocals prior, pitch shifted them up and then mimed so it looked like he was singing). Then they stopped. The hall, which had been silent while the band played, erupted into wild shouts of unrestrained enthusiasm.

I signed them like a shot. For the first time, here was a band I could represent that I didn't actually have to listen to.

But the real fun was taking the demo around to record companies, playing these ultrasonic songs to the guys in suits, and then telling them that only cool people could hear the music. Hans Christian Anderson would have loved it.

Screwing their faces up with concentration they'd lean forward and then they songs have faded. Your fans are putting on your music, and they can't hear it any more. It's not the songs that are fading your first lot of fans are about the same age as you, so they can press the play button as much as they like but nothing's gonna come out, at least not for them anymore."

"So?" he said.

"It's time for Nat to grow up and go solo," I said grinning. "To transpose all your songs into an audible register, re-record them as a series of duets with the hottest stars, and get your fans to buy them all over again. Welcome to the 'dults Nat, I think you'll find it much more fun than you were expecting."

Gareth Owens is a palaeolinguist and a student of the arcane writings of ancient and lost civilizations. $\mathrm{He}$ is a composer, writer and traveller and has recently completed a novel. 